\title{
Profile of Reproductive Issues Associated with Different Sickle Cell Disease Genotypes
}

\section{Perfil reprodutivo associado aos diferentes genótipos da doença falciforme}

\author{
Flávia Anchielle Carvalho ${ }^{1,2}$ Ariani Impieri Souza ${ }^{1,2}$ Ana Laura Carneiro Gomes Ferreira ${ }^{1}$ \\ Simone da Silva Neto ${ }^{2}$ Ana Carolina Pessoa de Lima Oliveira ${ }^{2}$ Maria Luiza Rodrigues Pinheiro Gomes ${ }^{2}$ \\ Manuela Freire Hazin Costa ${ }^{1,3}$
}

${ }^{1}$ Instituto de Medicina Integral Prof. Fernando Figueira (IMIP),

Address for correspondence Ariani Impieri Souza, PhD, Instituto de Recife, PE, Brazil

2 Faculdade Pernambucana de Saúde (FPS), Recife, PE, Brazil

3 Universidade Federal de Pernambuco (UFPE), Recife, PE, Brazil Medicina Integral Prof. Fernando Figueira (IMIP), Rua dos Coelhos, 300 Boa Vista, 50070-550-Recife, PE, Brazil (e-mail: ariani@imip.org.br).

Rev Bras Ginecol Obstet 2017;39:397-402.

\begin{abstract}
Purpose To describe the reproductive variables associated with different sickle cell disease $(S C D)$ genotypes and the influence of contraceptive methods on acute painful episodes among the women with the homozygous hemoglobin S (HbSS) genotype.

Methods A cross-sectional study was conducted between September of 2015 and April of 2016 on 158 women afflicted with SCD admitted to a hematology center in the Northeast of Brazil. The reproduction-associated variables of different SCD genotypes were assessed using the analysis of variance (ANOVA) test to compare means, and the Kruskal-Wallis test to compare medians. The association between the contraceptive method and the acute painful episodes was evaluated by the Chi-square test.

Results The mean age of women with SCD was 28.3 years and $86.6 \%$ were mixed or of African-American ethnicity. With respect to the genotypes, 134 women (84.8\%) had HbSS genotype, 12 women (7.6\%) had hemoglobin SC (HbSC) disease genotype, and $12(7.6 \%)$ were identified with hemoglobinopathy S-beta (S- $\beta$ ) thalassemia. The mean age of HbSS diagnosis was lower than that of HbSC disease, the less severe form of SCD $(p<0.001)$. The mean age of menarche was $14.8 \pm 1.8$ years for $\mathrm{HbSS}$ and $12.7 \pm 1.5$ years for HbSC $(p<0.001)$. Among women with HbSS who used progestin-only contraception, $16.6 \%$ had more than 4 acute painful episodes per year. There was no statistically significant difference when compared with other contraceptive

Keywords

- sickle cell disease

- sickle cell anemia

- menarche

- contraception methods.

Conclusion With respect to reproduction-associated variables, only the age of the menarche showed delay in HbSS when compared with HbSC. The contraceptive method used was not associated with the frequency of acute painful episodes among the HbSS women.
\end{abstract}

received

January 16, 2017

accepted

April 25, 2017

published online

July 6, 2017
DOI https://doi.org/

10.1055/s-0037-1604179.

ISSN 0100-7203.
Copyright @ 2017 by Thieme Revinter

Publicações Ltda, Rio de Janeiro, Brazil
License terms

(c) (1) $\ominus$ (\$) 


\section{Resumo}

\section{Palavras-Chave \\ - doença falciforme \\ - anemia falciforme \\ - menarca \\ - anticoncepção}

Objetivo Descrever as variáveis reprodutivas em diferentes genótipos da doença falciforme (DF) e a influência dos métodos contraceptivos na frequência das crises álgicas em mulheres com homozigose da hemoglobina S (HbSS).

Métodos Estudo de corte transversal realizado entre setembro de 2015 e abril de 2016 com 158 mulheres com DF atendidas em um centro de hematologia no Nordeste do Brasil. As variáveis reprodutivas dos diferentes genótipos da DF foram avaliadas utilizando-se o teste de análise de variância (ANOVA) para comparação de médias e o teste de Kruskal-Wallis para comparação de medianas. A associação entre o método contraceptivo e a frequência das crises álgicas foi avaliada pelo teste Qui-quadrado. Resultados A idade média das mulheres com DF foi de 28,3 anos e $86,6 \%$ eram afrodescentes. Em relação aos genótipos, 134 mulheres (84,8\%) tinham genótipo HbSS, 12 mulheres (7,6\%) tinham genótipo para doença da hemoglobina SC (HbSC) e 12 (7,6\%) foram identificadas com beta talassemia (S- $\beta$ ). A idade média do diagnóstico de HbSS foi menor do que a da HbSC, sendo esta a forma menos grave da DF $(p<0,001)$. A idade média da menarca foi de $14,8 \pm 1,8$ anos para HbSS e de $12,7 \pm 1,5$ anos para HbSC $(p<0,001)$. Entre as mulheres com HbSS que fizeram contracepção com progesterona isolada, $16,6 \%$ apresentaram mais de 4 episódios de crises álgicas agudas por ano. Não houve diferença estatisticamente significativa quando comparado com outros métodos anticoncepcionais.

Conclusão Em relação às variáveis reprodutivas, apenas a idade da menarca apresentou atraso no $\mathrm{HbSS}$ em relação ao HbSC. O método anticoncepcional utilizado não foi associado à frequência de crises álgicas entre as mulheres com HbSS.

\section{Introduction}

Sickle cell disease (SCD) includes any hemoglobinopathy in which the sickle mutation is inherited, such as homozygosity for hemoglobin S (HbSS, sickle cell anemia) and heterozygosity for hemoglobin $\mathrm{S}(\mathrm{HbS})$ with other hemoglobin anomalies, resulting in: hemoglobin SC disease (HbSC), hemoglobin SD disease, hemoglobinopathy $S$ - $\alpha$-thalassemia (S $\alpha$-thalassemia), hemoglobinopathy $S$ - $\beta$-thalassemia ( $S \beta$-thalassemia), and other less commons SCD genotypes. The disease course depends in part on the SCD genotype; HbSS tends to result in the most severe form of the disease, while a more benign course may occur with $\mathrm{HbSC}$, although adverse events have been observed in all genotypes. ${ }^{1}$

Sickle cell disease is associated with hypoxia-induced polymerization of the abnormal HbS molecule, followed by red blood cell injury and the sickling process. Consequently, a microvascular occlusion (vaso-occlusion) can occur and clinically manifest as hemolysis and acute painful episodes. ${ }^{2,3}$

Recently, the mortality of patients with SCD has decreased due to the better understanding of SCD physiopathology, allowing earlier diagnostic and therapeutic interventions, such as newborn screening, antibiotic prophylaxis with penicillin, immunization, the use of hydroxyurea, and multidisciplinary assistance. ${ }^{4}$ Consequently, reproductive issues will take a higher priority in $\mathrm{SCD}$, such as delay of pubertal development, delay of first pregnancy, complications in pregnancy and postpartum, and the choice of contraceptive method. ${ }^{4-8}$

Although several studies have demonstrated the influence of the HbSS genotype on some sexual and reproductive issues, there are limited data regarding other SCD genotypes. $^{5,7,9}$ The objective of this study was to describe the reproductive variables in different SCD genotypes and the influence of the contraceptive method on acute painful episodes among women with the HbSS genotype.

\section{Methods}

From September of 2015 to April of 2016, a cross-sectional study was performed on women with SCD. The subjects were between 14 and 47 years of age and had been treated at a Hematology and Hemotherapy Center in Pernambuco, in the Northeast of Brazil. The data were collected by interviewing 158 women who agreed to participate in the research and signed the Informed Consent Form. This study is part of a larger project, which was approved by the Research Ethics Board of the institution.

The sociodemographic, reproductive, and clinical data were collected via interview and examination of medical records, where the SCD genotype was checked. We considered painful crises to have occurred when the woman reported some episode of bone pain.

A database was created using the Microsoft Office Excel 2007 (Microsoft, USA) software. In the statistical analysis, we used the mean (standard deviation) when the numerical variable conformed to a normal distribution, and the median (interquartile range) when it was non-normal distribution. The reproductive variables of the different SCD genotypes were assessed by using the analysis of variance (ANOVA) test to compare means, and the Kruskal-Wallis test to compare the medians. 
When the ANOVA results indicated statistical significance, we performed the Tukey test. The association between the contraceptive method and the acute painful episodes was evaluated by the Chi-square test. The statistical analyses were performed with Stata version 12.1 (StataCorp LLC, College Station, USA), and the tests were considered statistically significant when the $p$-value was less than 0.05 .

\section{Results}

A total of 158 women with SCD were included in this study. Their ages ranged from 14 to 47 years, with a mean of 28.3 years. Out of the total population, $64.0 \%$ were from the metropolitan region of Recife, $86.6 \%$ had mixed or African-American ethnicity, $59.5 \%$ had 11 or more years of schooling, $36.7 \%$ were retired, and $25.3 \%$ had no occupation. A total of $54.4 \%$ reported the family income to be less than the minimum wage (MW) (-Table $\mathbf{1}$ ).

As for the genotypes, 134 women (84.8\%) had HbSS, 12 women (7.6\%) had HbSC, and 12 (7.6\%) were identified with $\mathrm{S} \beta$-thalassemia.

The mean age for SCD diagnosis for all women was $6.5 \pm 7.4$ years. There was a significant difference in the mean age at diagnosis between $\operatorname{HbSC}$ (18.9 \pm 9.2 years) and the other two groups $(p<0.001)$. A significant difference in the mean age for menarche was observed between the groups with $\mathrm{HbSS}$ ( $14.8 \pm 1.8$ years) and $\mathrm{HbSC}(12.7 \pm 1.5$ years $)$ $(p<0.001)$. There was no difference among the groups with regard to the mean age of first sexual intercourse $(p=0.119)$ and the first pregnancy $(p=0.248)$. The median number of pregnancies was one for HbSS and two for both HbSC and S $\beta$-thalassemia $(p=0.510)$. The median number of living children was one for all SCD genotypes ( $p=0.427$ ) (-Table 2).

Of the 130 women (82.3\%) who reported being sexually active, 93 used contraceptive methods. The majority used condoms (34.4\%), followed by combined hormonal contraceptives $(33.3 \%)$, and only $6.5 \%$ reported taking progestinonly contraceptives. However, 63 of $89(70.8 \%)$ women who got pregnant did not plan the last pregnancy, in spite of having received counseling on reproduction ( - Table $\mathbf{3}$ ).

In this study, we investigated the effect of the contraceptive methods on the frequency of acute painful episodes only in the HbSS group, since this is the most severe form of SCD.

We observed 4 or more acute painful episodes per year in $60.0 \%$ of the women using combined hormonal contraceptives, in $50.7 \%$ of the women using non-hormonal methods, and in $16.6 \%$ of those who used progestin-only contraception. There was no statistical difference between the progestin-only and the combined hormonal contraception $(p=0.072)$, and there was no statistical difference when comparing the progestin-only and the non-hormonal methods $(p=0.118)$. ( - Table 4$)$

\section{Discussion}

The women in this study were predominantly young, of mixed ethnicity, well educated, and of low income families, as would be expected in this population. The diagnosis of HbSC occurred
Table 1 Sociodemographic profile of women with sickle cell disease. Brazil, 2015-2016

\begin{tabular}{|c|c|c|}
\hline Variables & $\mathrm{n}=158$ & $\%$ \\
\hline \multicolumn{3}{|l|}{ Age $($ years $)($ mean $=28.3)$} \\
\hline$\leq 19$ & 23 & 14.5 \\
\hline $20-34$ & 93 & 58.9 \\
\hline$\geq 35$ & 42 & 26.6 \\
\hline \multicolumn{3}{|l|}{ Location } \\
\hline Recife & 50 & 31.6 \\
\hline Other cities in the RMA & 51 & 32.3 \\
\hline Countryside & 57 & 36.1 \\
\hline \multicolumn{3}{|l|}{ Ethnicity } \\
\hline Mixed & 99 & 62.6 \\
\hline African-American & 38 & $\begin{array}{l}24.0 \\
1.3\end{array}$ \\
\hline White & 17 & 10.8 \\
\hline Indigenous & 02 & 1.3 \\
\hline No information & 02 & 1.3 \\
\hline \multicolumn{3}{|l|}{ Schooling } \\
\hline 0 to 3 years & 07 & 4.4 \\
\hline 4 to 7 years & 18 & 11.4 \\
\hline 8 to 10 years & 39 & 24.7 \\
\hline$\geq 11$ years & 94 & 59.5 \\
\hline \multicolumn{3}{|l|}{ Occupation } \\
\hline No Job/Housewife & 40 & 25.3 \\
\hline Self-employed/Other & 27 & 17.1 \\
\hline Student & 33 & 20.9 \\
\hline Retired & 58 & 36.7 \\
\hline \multicolumn{3}{|l|}{ Family Income } \\
\hline$\leq 1 \mathrm{MW}$ & 86 & 54.4 \\
\hline $1-2 \mathrm{MW}$ & 36 & 22.8 \\
\hline$>2 \mathrm{MW}$ & 29 & 18.4 \\
\hline No information & 7 & 4.4 \\
\hline
\end{tabular}

Abbreviations: MW, minimum wage; RMA, Recife metropolitan area.

later than in the other groups. There was a delay in the age of menarche in the HbSS group compared with the HbSC group.

The ethnicity data of this study differ from the Brazilian population data, where most of the women with SCD are black. ${ }^{10,11}$ This difference of ethnicity can be explained because the women interviewed in this study self-reported to be of mixed ethnicity.

Most of the women reported more than 11 years of schooling. This reflects the findings of another Brazilian study, which showed an increase of schooling level for women over the years. Advances in therapeutics have improved survival rates of women with SCD and thus, there are increasing numbers of women enjoying a better quality of life. ${ }^{12}$ 
Table 2 Association between sickle cell disease genotypes and reproductive profile. Brazil, 2015/2016

\begin{tabular}{|c|c|c|c|c|c|}
\hline Variables & $\begin{array}{l}\text { All the genotypes } \\
(n=158)\end{array}$ & $\begin{array}{l}\text { HbSS } \\
(n=134)\end{array}$ & $\begin{array}{l}\text { HbSC disease } \\
(n=12)\end{array}$ & S $\beta$-thalassemia $(n=12)$ & $p$ \\
\hline & Mean (SD) & Mean (SD) & Mean (SD) & Mean (SD) & \\
\hline Age of diagnosis & $6.5(7.4)$ & $5.5(6.2)$ & $18.9(9.2)^{a}$ & $5.2(6.8)$ & $<0.001^{*}$ \\
\hline Age of menarche & $14.5(1.9)$ & $14.8(1.8)^{\mathrm{b}}$ & $12.7(1.5)^{\mathrm{b}}$ & $13.7(2.0)$ & $<0.001^{*}$ \\
\hline Age of first intercourse & $19.4(4.2)$ & $19.7(4.4)$ & $18.3(2.6)$ & $17.1(2.2)$ & $0.119^{*}$ \\
\hline \multirow[t]{2}{*}{ Age of first pregnancy } & $22.0(4.7)$ & $22.2(4.7)$ & $22.3(4.7)$ & $19.1(3.1)$ & $0.248^{*}$ \\
\hline & Median (IQR) & Median (IQR) & Median (IQR) & Median (IQR) & \\
\hline Number of pregnancies & $1(1-2)$ & $1(1-2)$ & $2(1-2)$ & $2(1-2)$ & $0.510^{* *}$ \\
\hline Number of living children & $1(1-2)$ & $1(1-1.5)$ & $1(1-1.5)$ & $1(1-2)$ & $0.427^{* *}$ \\
\hline
\end{tabular}

Abbreviations: HbSS, homozygous hemoglobin S; HbSC, hemoglobin sickle cell; IQR, interquartile range; SD: standard deviation. *ANOVA-to compare the means of the $\mathrm{HbSS}, \mathrm{HbSC}$ and S $\beta$-thalassemia. ${ }^{*}$ Kruskal-Wallis- to compare the medians of HbSS, $\mathrm{HbSC}$ and S $\beta$-thalassemia.

aThe difference was in this group (Tukey test).

bThe difference occurred only between these two groups (Tukey test).

Table 3 Reproductive variables of women with sickle cell disease. Brazil, 2015-2016

\begin{tabular}{|l|l|l|}
\hline Variables & $\mathbf{n}$ & $\%$ \\
\hline Sexual activity $(n=158)$ & 130 & 82.3 \\
\hline Yes & 28 & 17.3 \\
\hline No & \multicolumn{2}{|l|}{} \\
\hline Pregnancy history $(n=130)$ & 89 & 68.5 \\
\hline Yes & 41 & 31.5 \\
\hline No & \multicolumn{2}{|l|}{} \\
\hline Unplanned pregnancy $(n=89)$ & 63 & 70.8 \\
\hline Yes & 26 & 29.2 \\
\hline No & \multicolumn{2}{|l|}{} \\
\hline Contraceptive methods $(n=93)$ & 32 & 34.4 \\
\hline Condom & 31 & 33.3 \\
\hline Combined hormonal & 19 & 20.4 \\
\hline $\begin{array}{l}\text { Surgical methods } \\
\text { (vasectomy and tubal ligation) }\end{array}$ & & 6.5 \\
\hline Progestin-only & 6 & 5.4 \\
\hline Others & 5 & \\
\hline
\end{tabular}

The higher educational level in this study was not reflected by these women's income. More than half earned a monthly family income of minimum wage or less. These data agree with other studies that show less access to paid labor activity among the population with SCD, possibly due to the high absenteeism caused by the clinical events of the disease..$^{2,13}$

The mean age for HbSS diagnosis was around 5.5 years. This is high, considering that the National Neonatal Screening Program can diagnose hemoglobinopathy at birth. However, the program was established in 2001, when the majority of the women in this study had already been born. ${ }^{14}$ The mean age for HbSC diagnosis (18.9 years), which displays milder clinical conditions, was later than that of the other groups. ${ }^{5}$
The mean age of menarche for HbSS was 14.8 years. This result is supported by other studies that showed a delay of menarche for this condition. 7,15,16 The delay in menarche may be associated with a weight deficit and the delay of skeletal development. It seems reasonable to postulate that the phenomenon of vaso-occlusion may interfere with physiologic mechanisms of growth hormone release in these women. $6,9,16$ The socioeconomic factors seem to contribute as well to the delay of the menarche in these women. This hypothesis is supported by a study of Jamaican girls by Alleyne et $\mathrm{al}^{16}{ }^{16}$ which showed that poorer and less educated women experienced their first menstruation later than those in a better economic and educational situation. When comparing the HbSS and HbSC groups, the difference in age of the menarche was statistically significant in accordance with the Jamaican data. ${ }^{5}$ The delay of the menarche may occur due to HbSC resulting in fewer vasoocclusive events and fewer clinical consequences. ${ }^{5,17}$

In this present study, the mean age of first sexual intercourse and of the first pregnancy showed no difference between the genotypes. A Jamaican study comparing women with HbSS to a control group (women without the disease) did not find any difference, suggesting that HbSS does not influence fertility. $^{16}$

The median number of pregnancies of women with HbSS was lower than the median in the other groups; however, there was no statistical significance, possibly due to the small sample size of the other SCD genotypes. Studies relate HbSS to a smaller number of pregnancies due to factors such as reduction in the frequency of sexual intercourse, fear of becoming pregnant due to the high incidence of fetal loss in pregnancy, and increased risk of morbimortality during pregnancy and during the postpartum period., ${ }^{4,16}$

There was no difference in the number of living children among the SCD genotypes, in contrast to the findings by Serjeant et al. ${ }^{5}$ According to their data, the women with HbSS had a lower number of living children when compared with women with HbSC. This divergence may be due to the small sample size of women with HbSC in this present study. In 
Table 4 Association between the type of contraceptive method and frequency of acute painful episodes in 108 women with homozygous hemoglobin S (HbSS). Brazil, 2015/2016

\begin{tabular}{|c|c|c|c|c|c|}
\hline \multirow[t]{3}{*}{ Contraceptive method } & \multicolumn{4}{|c|}{ Frequency of acute painful episodes last year } & \multirow{3}{*}{$p^{*}$} \\
\hline & \multicolumn{2}{|c|}{ Up to 3 episodes/year } & \multicolumn{2}{|c|}{$\begin{array}{l}4 \text { or more } \\
\text { episodes/year }\end{array}$} & \\
\hline & $\mathrm{N}$ & $\%$ & $\mathrm{n}$ & $\%$ & \\
\hline Progestin-only $(n=6)$ & 5 & 83.4 & 1 & 16.6 & 0.093 \\
\hline Combined hormonal $(n=35)$ & 10 & 40.0 & 15 & 60.0 & 0.072 \\
\hline Non-hormonal methods $(n=73)$ & 36 & 49.3 & 37 & 50.7 & 0.118 \\
\hline Total & 51 & 49.0 & 53 & 51.0 & \\
\hline
\end{tabular}

*Fisher Test.

Brazil, a study showed that most women with HbSS had only one living child. ${ }^{15}$ These women have high morbimortality, with increased risk of prematurity, low birth weight, restricted intrauterine growth, and perinatal mortality. ${ }^{18}$

The majority of women who got pregnant reported that they did not plan to get pregnant, despite having received counseling about pregnancy risks. This supports the idea that the final decision in using a contraceptive method is complex, and difficult to assess in quantitative studies. ${ }^{19,20}$ In addition to each woman's individual issues, this decision may be influenced by their complex health condition, since there is no robust evidence regarding the safety of various contraceptive methods in women with SCD. ${ }^{8}$

Among the users of contraceptive methods, most mentioned the use of condoms or combined hormonal methods. The frequency of combined hormonal contraceptive use found in this study is greater than the frequency found by Qureshi et al, ${ }^{21}$ probably because combined hormonal contraception is the most widespread method in Brazil, according to a population-based survey conducted in $2006 .^{22}$

In the HbSS group, $83.4 \%$ of women who used progestinonly contraception had up to three acute painful episodes in the past year, and $40 \%$ of the users of the estrogen-progesterone combination had up to three acute painful episodes, but we did not find any statistically significant difference.

The effects of progesterone on the clinical parameters of SCD are still unclear. A systematic review examined the safety of hormonal contraceptive methods used among women with SCD and found that the progestin-only method has been associated with a decrease in painful episodes. ${ }^{8}$ Isaacs suggested, in 1967 that the progestin-only contraception methods might increase the stability of the membranes of the red blood cells subject to the sickling phenomenon. ${ }^{23}$

One of the limitations of this present study was the predominance of women with HbSS, and a small number of women with $\mathrm{HbSC}$ or S $\beta$-thalassemia. This poses difficulties in comparing the SCD genotype groups. Prospective studies with larger samples could reveal differences that may not have been observed in this study. Another limitation may be the low frequency of the use of progestin-only contraception, preventing observation of the differences in the frequency of the acute painful episodes among the different contraceptive methods.

\section{Conclusion}

In the evaluation of reproductive aspects, only the age of the menarche showed a delay in HbSS women when compared with HbSC women. The contraceptive method used was not associated with the frequency of the acute painful episodes among the HbSS women.

Conflict of Interests

The authors declare no conflict of interests.

\section{References}

1 Modell B, Darlison M. Global epidemiology of haemoglobin disorders and derived service indicators. Bull World Health Organ 2008;86(06):480-487

2 Felix AA, Souza HM, Ribeiro SBF. Aspectos epidemiológicos e sociais da doença falciforme. Rev Bras Hematol Hemoter 2010; 32(03):203-208

3 Brasil. Ministério da Saúde. Instituto Sírio-Libanês de Ensino e Pesquisa. Protocolo de atenção básica: saúde das mulheres. Brasília (DF): Ministério da Saúde; 2016

4 Rogers DT, Molokie R. Sickle cell disease in pregnancy. Obstet Gynecol Clin North Am 2010;37(02):223-237

5 Serjeant GR, Hambleton I, Thame M. Fecundity and pregnancy outcome in a cohort with sickle cell-haemoglobin C disease followed from birth. BJOG 2005;112(09):1308-1314

6 Verissimo MPA. Crescimento e desenvolvimento nas doenças falciformes. Rev Bras Hematol Hemoter 2007;29(03):271-274

7 Balgir RS. Age at menarche and first conception in sickle cell hemoglobinopathy. Indian Pediatr 1994;31(07):827-832

8 Haddad LB, Curtis KM, Legardy-Williams JK, Cwiak C, Jamieson DJ. Contraception for individuals with sickle cell disease: a systematic review of the literature. Contraception 2012;85(06):527-537

9 Serjeant GR, Singhal A, Hambleton IR. Sickle cell disease and age at menarche in Jamaican girls: observations from a cohort study. Arch Dis Child 2001;85(05):375-378

10 Lopes TO, Amorim ACM, Oliveira DL, et al. Prevalência de casos de anemia falciforme, no ano de 2014, registrados na Secretaria Municipal de Saúde de Paracatu-MG. Rev Med Fac Atenas. 2015; $9(01): 1-5$

11 Brasil. Ministério da Sáude. Secretaria de Atenção à Saúde. Departamento de Atenção Hospitalar e de Urgência. Coordenação-Geral de Sangue e Hemoderivados. Doença falciforme: atenção integral à saúde das mulheres. Brasilía (DF): Ministério da Saúde; 2015 
12 de Paiva e Silva RB, Ramalho AS, Cassorla RM. Sickle cell disease as a public health problem in Brazil. Rev Saude Publica 1993;27(01):54-58

13 Cordeiro RC, Ferreira SL. [Racial and gender discrimination on the discourses of black women with sickle cell anemia]. Esc Anna Nery 2009;13(02):352-358 Portuguese

14 Brasil. Ministério da Sáude. Triagem neonatal triagem neonatal: manual de normas técnicas e rotinas operacionais do programa nacional de triagem neonatal. Brasília(DF): Ministério da Saúde; 2002

15 Côbo VdeA, Chapadeiro CA, Ribeiro JB, Moraes-Souza H, Martins PRJ. Sexuality and sickle cell anemia. Rev Bras Hematol Hemoter 2013;35(02):89-93

16 Alleyne SI, Rauseo RD, Serjeant GR. Sexual development and fertility of Jamaican female patients with homozygous sickle cell disease. Arch Intern Med 1981;141(10):1295-1297

17 Clive Ellory J. Haemoglobin C promotes distinct membrane properties in heterozygous HbSC red cells. EBioMedicine 2015; 2(11):1577
18 Zanette AMD. Gravidez e contracepção na doença falciforme. Rev Bras Hematol Hemoter 2007;29(03):309-312

19 Dehlendorf C, Levy K, Kelley A, Grumbach K, Steinauer J. Women's preferences for contraceptive counseling and decision making. Contraception 2013;88(02):250-256

20 Upadhyay UD, Brown BA, Sokoloff A, Raine TR. Contraceptive discontinuation and repeat unintended pregnancy within 1 year after an abortion. Contraception 2012;85(01):56-62

21 Qureshi AI, Malik AA, Adil MM, Suri MFK. Oral contraceptive use and incident stroke in women with sickle cell disease. Thromb Res 2015;136(02):315-318

22 Brasil. Ministério da Saúde. Pesquisa Nacional de Demografia e Saúde da Criança e da Mulher: PNDS 2006: dimensões do processo reprodutivo e da saúde da criança. Brasília (DF): Ministério da Saúde; 2009

23 Isaacs WA, Hayhoe FGJ. Steroid hormones in sickle-cell disease. Nature 1967;215(5106):1139-1142 